\title{
Genetic variability in clones of 'Prata Anã' bananas based on phenotypic and molecular markers
}

\author{
Francisco Ermelindo Rodrigues ( $\left.{ }^{(}\right)$; Samira Santiago Librelon ( $\left.{ }^{2}\right)$; Silvia Nietsche $\left({ }^{1 *}\right)$; \\ Márcia Regina Costa ('); Marlon Cristian Toledo Pereira (') \\ (') Universidade Estadual de Montes Claros, Departamento de Ciências Agrárias, Programa de Pós-Graduação em Produção Vegetal \\ no Semiárido, Caixa Postal 91, 39440-000 Janaúba (MG), Brasil. \\ (2) Universidade Federal de Lavras, Departamento de Biologia, Programa de Pós-Graduação em Genética e Melhoramento de \\ Plantas, Caixa Postal 3037, 37200-000 Lavras (MG), Brasil. \\ (*) Corresponding author: silvia.nietsche@unimontes.br
}

Received: Dec. 13, 2011; Accepted: May 23, 2012

\begin{abstract}
The objective of this study was to examine the molecular and phenotypic variability of 'Prata Anã' banana clones cultivated in northern Minas Gerais State. For the phenotypic and molecular characterization, the clones were collected from five properties. The morphological characterization of 20 clones was accomplished through a qualitative evaluation of 74 descriptors. For the molecular evaluations, 45 clones were collected, and 14 Random Amplified Polymorphic DNA primers were used. Among the 74 morphological descriptors evaluated in the 20 'Prata Anã' banana tree clones, 53 descriptors presented in the same homogeneous class for all clones. The presence of anthocyanin in the pseudostem (ANT) and the shape (BUS) and flexion (FLX) of the bunch clearly differentiated the 'Prata Anã' banana clones from the commercial cultivar. A total of 176 bands were produced from the molecular analysis using the 14 RAPD primers; there were 116 monomorphic and 60 polymorphic bands, with an average polymorphism percentage of 52.2\%. The amplification using the OPP 14 primer resulted in the greatest percentage of polymorphic bands at $88 \%$. The dendrogram indicated that each of the 45 'Prata Anã' clones that were evaluated using RAPD markers clustered with the commercial 'Prata Anã' cultivar.
\end{abstract}

Key words: Musa spp., morphological variation, diversity, clonal population, RAPD.

\section{Variabilidade genética em clones de bananeira 'Prata Anã' por meio de marcadores fenotípico e molecular}

Resumo

O objetivo do presente estudo foi avaliar a variabilidade fenotípica e molecular de clones de bananeira 'Prata Anã' cultivados no Norte de Minas Gerais. Os clones foram coletados em cinco propriedades. A caracterização morfológica de 20 clones foi realizada por meio da avaliação qualitativa de 74 descritores. Para a avaliação molecular, 45 clones foram coletados e 14 primers RAPD foram utilizados. Dentre os 74 descritores morfológicos avaliados nos 20 clones de bananeira 'Prata Anã', 53 descritores tinham a mesma classe, sendo homogêneos para todos os clones. Dentre os descritores avaliados, a presença de antocianina no pseudocaule (ANT), a forma do cacho (FCA) e a flexão das pencas (FLX) diferenciaram de maneira clara os clones de 'Prata Anã' da cultivar comercial. Por meio da amplificação de 14 iniciadores RAPD foram produzidos o total de 176 bandas, sendo 116 monomórficas e 60 polimórficas, média de 52,2\% de polimorfismo. O primer OPP14 produziu a maior porcentagem de bandas polimórficas, 88\%. Pelo dendrograma observou-se que todos os 45 clones avaliados por meio do uso dos marcadores RAPD agruparam com a cultivar 'Prata Anã'.

Palavras-chave: Musa spp., variação morfológica, diversidade, população clonal, RAPD.

\section{INTRODUCTION}

Among the most common banana cultivars in the Brazilian market are the 'Prata,' 'Nanica,' 'Maçã,' 'Terra,' 'Ouro' and 'Marmelo' varieties. The narrow genetic variability of the Brazilian cultivars makes these bananas vulnerable to disease (Silva et al., 2008).

According to Lichtemberg and Lichtemberg (2011) the 'Branca' banana (AAB) originated in Santa Catarina State, and a natural mutation gave rise to the 'Enxerto'. The Enxerto cultivar was registered at the germplasm bank of the Centro Nacional de Pesquisa Mandioca e Fruticultura (CNPMF) in the 1970s. It later received the name 'Prata Anâ' and was distributed worldwide and throughout various regions of Brazil.

Notable morphological characteristics of the 'Prata Anä' banana tree include the bright green coloration of its pseudostem sheaths. Under favorable cultivation conditions, the pseudostem girth normally exceeds one meter with a height from the ground to the foliar rosette between 2.20 and 4.50 meters (MARQues et al., 2011).

Since their introduction to northern Minas Gerais in the 1990s, innumerable farmers have selected 'Prata Anä' clones. A somaclonal variant known as 'Prata Anã Gorutuba' has been used for the expansion of new plantation areas (Rodrigues, 2009). 
Several methods have been used to investigate the genetic variability present in the Musa germplasm. Morphotaxonomic descriptors were the first to be developed and perfected for banana trees, and 119 descriptors were recently defined as normal for the Musa germplasm (IPGRI, 1996). More recently, molecular markers have been applied to studies concerning the genotypic relationships (SHINwARI, 1995), identification of mutants (DAMAsco et al., 1996), and classification of clones (BHat et al., 1995) of the Musa spp.

The analysis of genetic diversity based on RAPD molecular markers is a technique used for studies of inter - and intra-varietal genetic variability among different species (Solouki et al., 2008, Martins-Lopes et al., 2009). One of the advantages of molecular markers is phenotypic neutrality, which is generally co-dominantly inherited and rarely exhibits epistatic or pleiotropic interactions, allowing it to be detected in both young and adult tissues (BRAMMER, 2000).

The objective of the present study was to analyze the phenotypic and molecular variability of 'Prata Anã' banana clones cultivated in northern Minas Gerais.

\section{MATERIAL AND METHODS}

\section{Morphological Characterization}

The morphological characterization of the clones was conducted at five properties located in the northern region of Minas Gerais with orchards of 'Prata Anä' banana trees. Sucker plants were obtained using an in vitro micropropagation process. All plants selected had completed at least two productive cycles (possessing a third cluster). Four plants from each property were characterized, for a total of 20 plants. The geographic location of the properties used in the morphological characterization was defined using a GPSMAP 76S Garmin device with the South American Datum 1969 (SAD 69) standard (Tables 1 and 2).

The descriptors evaluated in the selected plants were compared with 'Prata Anä' from the official accession of the EMBRAPA CNPMF Germplasm Active Bank; this accession is located at Cruz das Almas, BA (12040'34.0"S; $39^{\circ} 05^{\prime} 17.2$ "W; altitude of $217 \mathrm{~m}$ ).

Table 1. The collection county, geographic location and code among the 'Prata Anä' banana clones collected in northern Minas Gerais

\begin{tabular}{cccccc} 
County-State & Farm & $\begin{array}{c}\text { Clones } \\
\text { Code }\end{array}$ & Altitude (m) & Latitude & Longitude \\
Nova Porteirinha (MG) & Uvale & PGFU & 563,5 & $15^{\circ} 45^{\prime} 51,2^{\prime \prime} \mathrm{S}$ & $43^{\circ} 15^{\prime} 46,2^{\prime \prime}$ W \\
\hline Janaúba (MG) & Belém & PGFB & 544,2 & $15^{\circ} 44^{\prime} 42,7^{\prime \prime} \mathrm{S}$ & $43^{\circ} 18^{\prime} 39,7^{\prime \prime}$ W \\
\hline Janaúba (MG) & Piranhas & PGFC & 530,2 & $15^{\circ} 44^{\prime} 50,7^{\prime \prime} \mathrm{S}$ & $43^{\circ} 19^{\prime} 27,4^{\prime \prime} \mathrm{W}$ \\
\hline Jaíba (MG) & Thelo & PGZT & 479,5 & $15^{\circ} 15^{\prime} 04,9^{\prime \prime} \mathrm{S}$ & $43^{\circ} 55^{\prime} 19,1^{\prime \prime}$ W \\
\hline Jaíba (MG) & Odilia & PGFS & 479,1 & $15^{\circ} 15^{\prime} 32,3^{\prime \prime} \mathrm{S}$ & $43^{\circ} 48^{\prime} 01,5^{\prime \prime}$ W \\
\hline
\end{tabular}

Table 2. Plant identification, clone codes and types of analysis, phenotypic (P) and molecular (M) performed of 48 "Prata Anâ" clones and the Prata Anã cultivar

\begin{tabular}{|c|c|c|c|c|c|}
\hline Plant Identification & Clones Code & $\begin{array}{l}\text { Type of } \\
\text { Analysis }\end{array}$ & Plant Identification & Clones Code & Type of Analysis \\
\hline Prata Anã Gorutuba 1 & PGFU 1 & $\mathrm{M}$ and $\mathrm{P}$ & Prata Anã Gorutuba 26 & PGZT6 & M \\
\hline Prata Anã Gorutuba 2 & PGFU 2 & $\mathrm{M}$ and $\mathrm{P}$ & Prata Anã Gorutuba 27 & PGZT7 & M \\
\hline Prata Anã Gorutuba 3 & PGFU 3 & M & Prata Anã Gorutuba 28 & PGZT8 & $\mathrm{M}$ and $\mathrm{P}$ \\
\hline Prata Anã Gorutuba 4 & PGFU 4 & M & Prata Anã Rio 29 & PGZT9 & M \\
\hline Prata Anã Gorutuba 5 & PGFU 5 & $\mathrm{M}$ and $\mathrm{P}$ & Prata Anã Rio 30 & PGZT 10 & M \\
\hline Prata Anã Gorutuba 6 & PGFU 7 & $\mathrm{M}$ and $\mathrm{P}$ & Prata Anã Rio 31 & PGZT11 & M \\
\hline Prata Anã Gorutuba 7 & PGFU 8 & M & Prata Anã Rio 32 & PGZT12 & M \\
\hline Prata Anã Gorutuba 8 & PGFB 1 & $\mathrm{M}$ and $\mathrm{P}$ & Prata Anã Rio 33 & PGZT13 & M \\
\hline Prata Anã Gorutuba 9 & PGFB 2 & $\mathrm{P}$ & Prata Anã Rio 34 & PGZT14 & M \\
\hline Prata Anã Gorutuba 10 & PGFB 3 & M & Prata Anã Rio 35 & PGZT15 & M \\
\hline Prata Anã Gorutuba 11 & PGFB 4 & $\mathrm{P}$ & Prata Anã Gorutuba 36 & PGFS 1 & M \\
\hline Prata Anã Gorutuba 12 & PGFB 5 & $\mathrm{M}$ and $\mathrm{P}$ & Prata Anã Gorutuba 37 & PGFS 3 & $\mathrm{M}$ and $\mathrm{P}$ \\
\hline Prata Anã Gorutuba 13 & PGFB 6 & M & Prata Anã Gorutuba 38 & PGFS 4 & $\mathrm{M}$ and $\mathrm{P}$ \\
\hline Prata Anã Gorutuba 14 & PGFB 7 & M & Prata Anã Gorutuba 39 & PGFS 5 & M \\
\hline Prata Anã Gorutuba 15 & PGFC 1 & $\mathrm{M}$ and $\mathrm{P}$ & Prata Anã Gorutuba 40 & PGFS 6 & M \\
\hline Prata Anã Gorutuba 16 & PGFC 2 & M & Prata Anã Gorutuba 41 & PGFS 7 & $\mathrm{M}$ and $\mathrm{P}$ \\
\hline Prata Anã Gorutuba 17 & PGFC 3 & $\mathrm{M}$ and $\mathrm{P}$ & Prata Anã Catarina 42 & PGFS 8 & M \\
\hline Prata Anã Gorutuba 18 & PGFC 4 & M & Prata Anã Catarina 43 & PGFS 9 & $\mathrm{M}$ and $\mathrm{P}$ \\
\hline Prata Anã Gorutuba 19 & PGFC 5 & $\mathrm{M}$ and $\mathrm{P}$ & Prata Anã Catarina 44 & PGFS 10 & M \\
\hline Prata Anã Gorutuba 20 & PGFC 6 & $\mathrm{P}$ & Prata Anã Catarina 45 & PGFS 11 & M \\
\hline Prata Anã Gorutuba 21 & PGFC 7 & M & Prata Anã Catarina 46 & PGFS 12 & M \\
\hline Prata Anã Gorutuba 22 & PGZT1 & $\mathrm{M}$ and $\mathrm{P}$ & Prata Anã Catarina 47 & PGFS 13 & M \\
\hline Prata Anã Gorutuba 23 & PGZT2 & M & Prata Anã Catarina 48 & PGFS 14 & M \\
\hline Prata Anã Gorutuba 24 & PGZT4 & $\mathrm{M}$ and $\mathrm{P}$ & Prata Anã cultivar & PC & $\mathrm{M}$ and $\mathrm{P}$ \\
\hline Prata Anã Gorutuba 25 & PGZT5 & $\mathrm{M}$ and $\mathrm{P}$ & - & - & - \\
\hline
\end{tabular}


The qualitative characteristics were determined by the consensus of the evaluations of three different researchers. The adult leaves from mature plants and suckers were evaluated at each clump or production unit (mother, daughter and granddaughter).

The morphological characterization was conducted through the qualitative evaluation of 74 descriptors, including 24 plant, 25 cluster and 25 inflorescence characteristics (heart and male flowers). The descriptors used are detailed and illustrated according to the International Plant Genetic Resources Institute (IPGRI, 1996). The data were subjected to a hierarchical agglomerative cluster analysis (HAC). Similarity dendrograms were established using Pearson's correlation coefficient, and the dendrogram was produced using the XLSTAT ${ }^{\circledR}$ software for Excel.

\section{Molecular Characterization}

For the molecular characterization, 45 'Prata Anä' banana tree clones from five properties located in the northern region of the state of Minas Gerais and the 'Prata Anä' cultivar from the EMBRAPA CNPMF Germplasm Active Bank were evaluated (Table 2).

Leaf samples from 31 'Prata Anã Gorutuba' clones, 7 'Prata Rio' clones, 7 'Prata Catarina' (EX-033) clones, and the common 'Prata Anâ' cultivar were collected, identified, and sent to the laboratory for DNA extraction.

DNA was extracted from young leaves in accordance with the methods of Doyle and Doyle (1990). The DNA was quantified spectrophotometrically (FEMTO 700 Plus), and the quality of the DNA was assessed on a $0.8 \%$ agarose gel. After estimating the quantity of the DNA, the samples were adjusted to a concentration of $10 \mathrm{ng} / \mu \mathrm{L}$. A total of 14 primers (decamers) were selected and used for amplification (Table 3). The RAPD reactions were performed according to Williams et al. (1990) with the following concentrations: genomic DNA (30 ng), Tris $\mathrm{HCl}-\mathrm{KCl}(10 \mathrm{mM} / 50 \mathrm{mM})$, $\mathrm{MgCl}_{2}(3 \mathrm{mM})$, dNTPs $(0.1 \mathrm{mM})$, primer $(0.4 \mu \mathrm{M})$, Taq DNA polymerase (1 unit), and distilled water in a final volume of $25 \mu \mathrm{l}$. Amplification was performed in a Techne TC-412 thermal cycler with the following program: one cycle of $94^{\circ} \mathrm{C}$ for 3 minutes, forty cycles of $94^{\circ} \mathrm{C}$ for 10 seconds, $35^{\circ} \mathrm{C}$ for 30 seconds and $72^{\circ} \mathrm{C}$ for 1 minute, followed by a final cycle of 7 minutes at $72^{\circ} \mathrm{C}$. The amplification products were subjected to electrophoresis on a 1.2\% agarose gel at $5 \mathrm{~V} / \mathrm{cm}$ in $1 \mathrm{X}$ TBE buffer for three hours. The gel was stained with a $5 \mathrm{mg} / \mathrm{ml}$ ethidium bromide solution. The amplified fragments were visualized under UV light and photographed using a UVP ${ }^{\circledR}$ Life Science software digital photo documentation system. Only the distinct and reproducible fragments were considered. The presence of an amplification product was classified as 1 , and the absence of product was classified as 0 . A matrix of binary data was prepared, and the Jaccard coefficient of similarity was applied. Estimates of dissimilarity were used to construct a dendrogram according to the Unweighted Pair Groups Method with Arithmetic Mean (UPGMA). A bootstrap analysis was performed with 1000 repetitive samplings of the RAPD data to compute $\mathrm{p}$ values. The data were analyzed using the statistical program Genes (Cruz, 2006).

\section{RESULTS AND DISCUSSION}

\section{Morphological Characterization}

Among the 74 morphological descriptors evaluated in the 20 'Prata Anä' banana tree clones, 53 presented in the same homogeneous class for all of the clones. The 21 descriptors that presented in different classes were submitted to a hierarchical agglomerative cluster analysis (HAC), establishing similarity dendrograms using Pearson's correlation coefficient (Figures 1 to 3 ).

Table 3. The RAPD markers produced with the 14 primers among 45 different 'Prata Anã' banana clones and the Prata Anã cultivar

\begin{tabular}{|c|c|c|c|c|}
\hline Primer & Sequence $5^{\prime}-3$ ' & Total bands & $\begin{array}{c}\text { Polymorphic } \\
\text { Bands }\end{array}$ & $\begin{array}{l}\text { Polymorphism } \\
\text { percentage (\%) }\end{array}$ \\
\hline OPC 07 & GTCCCGACG A & 5 & 2 & 40 \\
\hline OPN 11 & TCGCCGCAA A & 9 & 4 & 44 \\
\hline OPD 04 & TCTGGT GAG G & 10 & 2 & 20 \\
\hline OPQ 11 & TCTCCGCAA C & 9 & 3 & 33 \\
\hline OPH 14 & ACCAGGTTG G & 9 & 4 & 44 \\
\hline OPB 10 & CTGCTGGGA C & 11 & 6 & 55 \\
\hline OPG 17 & ACGACCGAC A & 11 & 6 & 55 \\
\hline OPA 10 & GTGATCGCA G & 10 & 5 & 50 \\
\hline OPP 14 & CCAGCCGAA C & 8 & 7 & 88 \\
\hline OPU 10 & ACCTCGGCA C & 10 & 6 & 60 \\
\hline OPO 10 & TCA CAG CGC C & 5 & 2 & 40 \\
\hline OPY 20 & AGCCGTGGA A & 6 & 3 & 50 \\
\hline Total & & 116 & 60 & \\
\hline
\end{tabular}




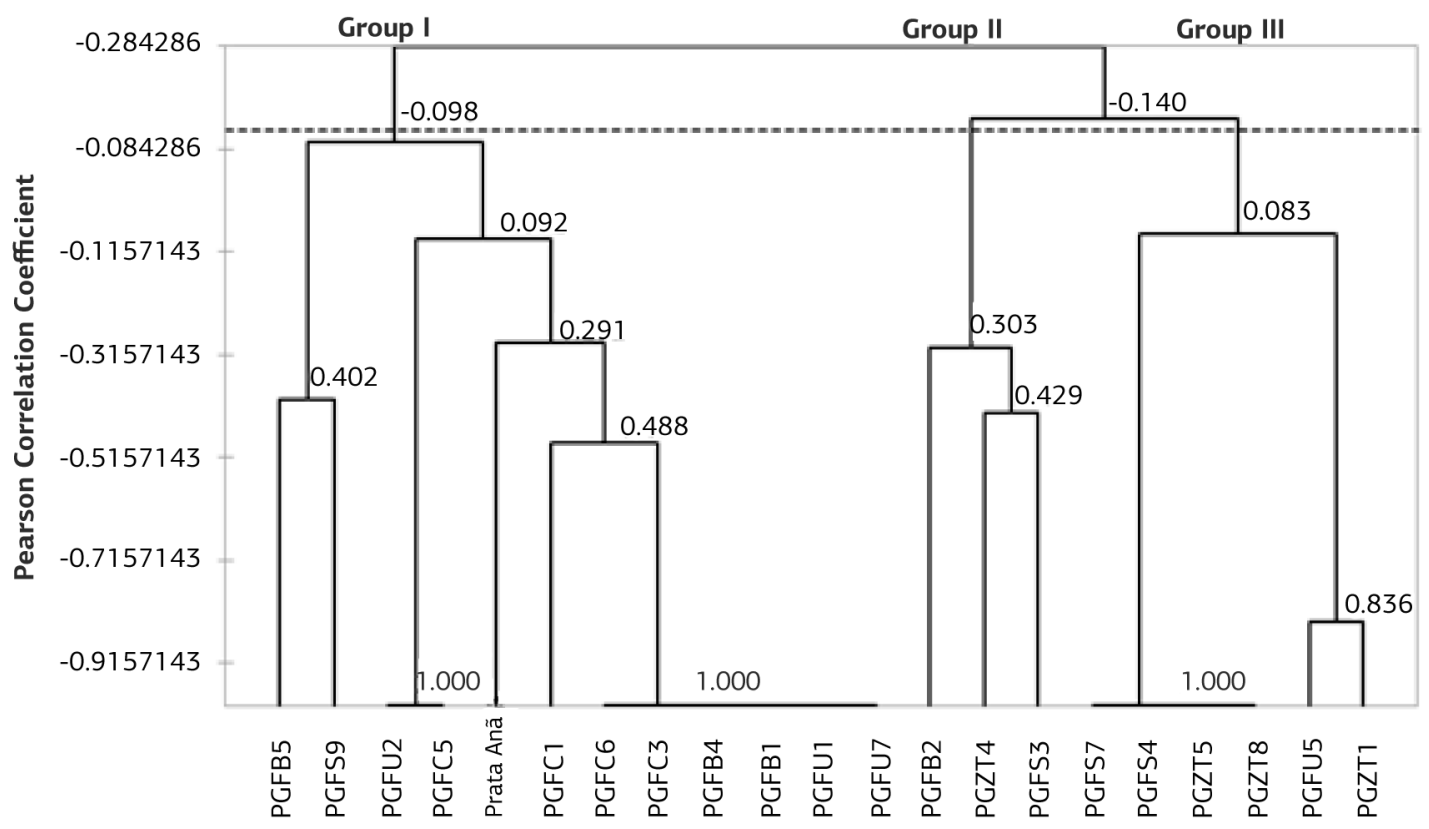

Figure 1. Distribution of Pearson's correlation coefficients observed among the morphological characteristics (GCH, WAX, DSC, ANT, DSD, PMS, PCB, PCB, DSW) of 20 'Prata Anã' banana tree clones and the 'Prata Anã' cultivated in northern Minas Gerais.

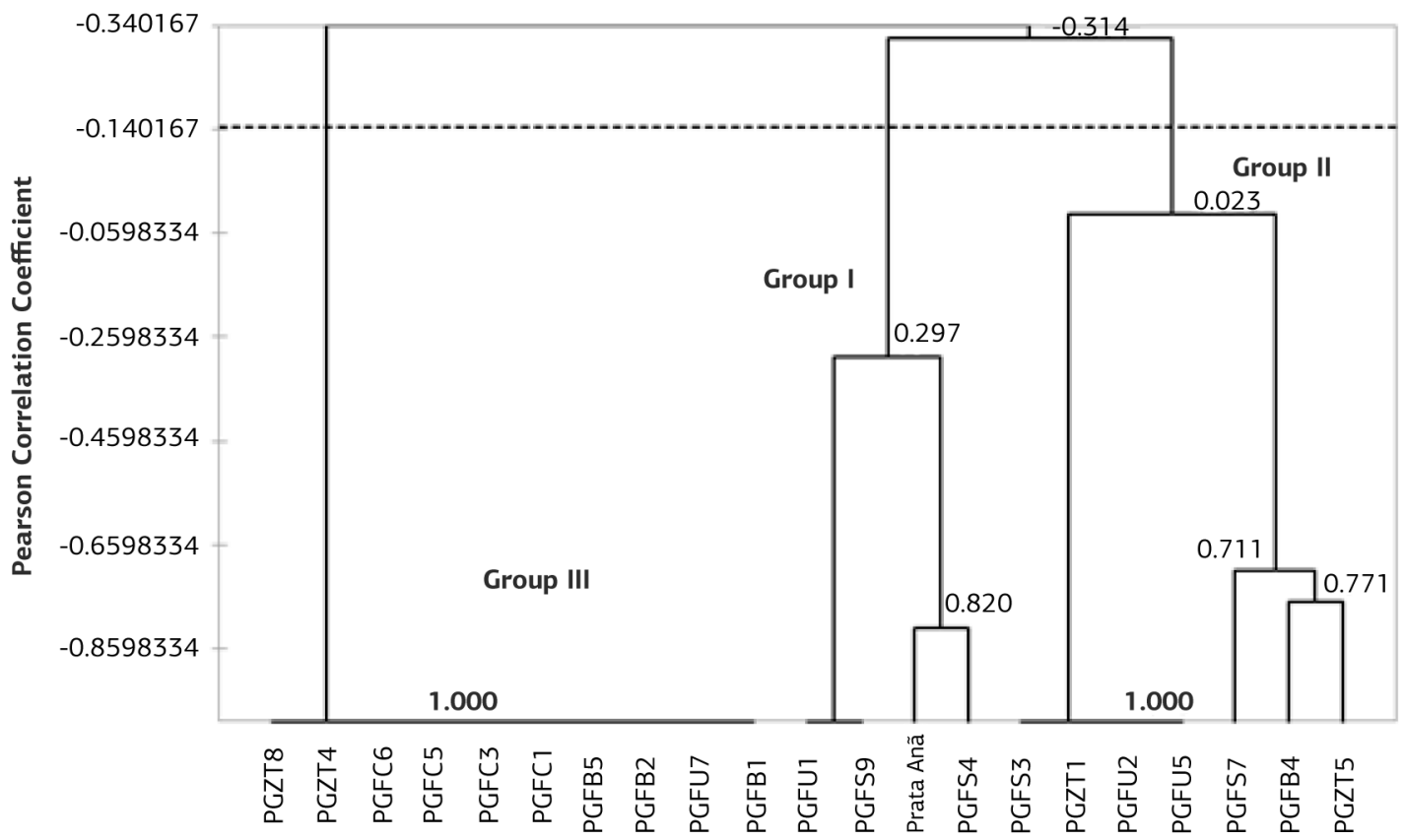

Figure 2. Distribution of the Pearson's correlation coefficients observed in the cluster characteristics (BUS, FLX, PSF, MPR and BRP) of 20 'Prata Anä' banana tree clones and the 'Prata Ana' cultivated in northern Minas Gerais.

Differences in nine plant descriptors, including green color hue $(\mathrm{GCH})$, waxiness (WAX), dark spot color (DSC), presence and quantity of anthocyanin in the pseudostem (ANT), dark spot density (DSD), petiole edge color (PMS), petiole colored band form and size (PCB), and dorsal surface limb waxiness (DSW), resulted in the classification of three groups. Pearson's correlation coefficient analysis showed that the six clones of group I presented $100 \%$ similarity and a significant correlation (0.488) with 'Prata Anä'. However, a negative Pearson's correlation coefficient $(-0.284)$ was recorded between the three groups (Figure 1).

The waxiness characteristic (WAX) showed higher variation between the Prata Aná cultivar and the evaluated clones, therefore, environmental factors such as climate and plant nutrition significantly influenced this 


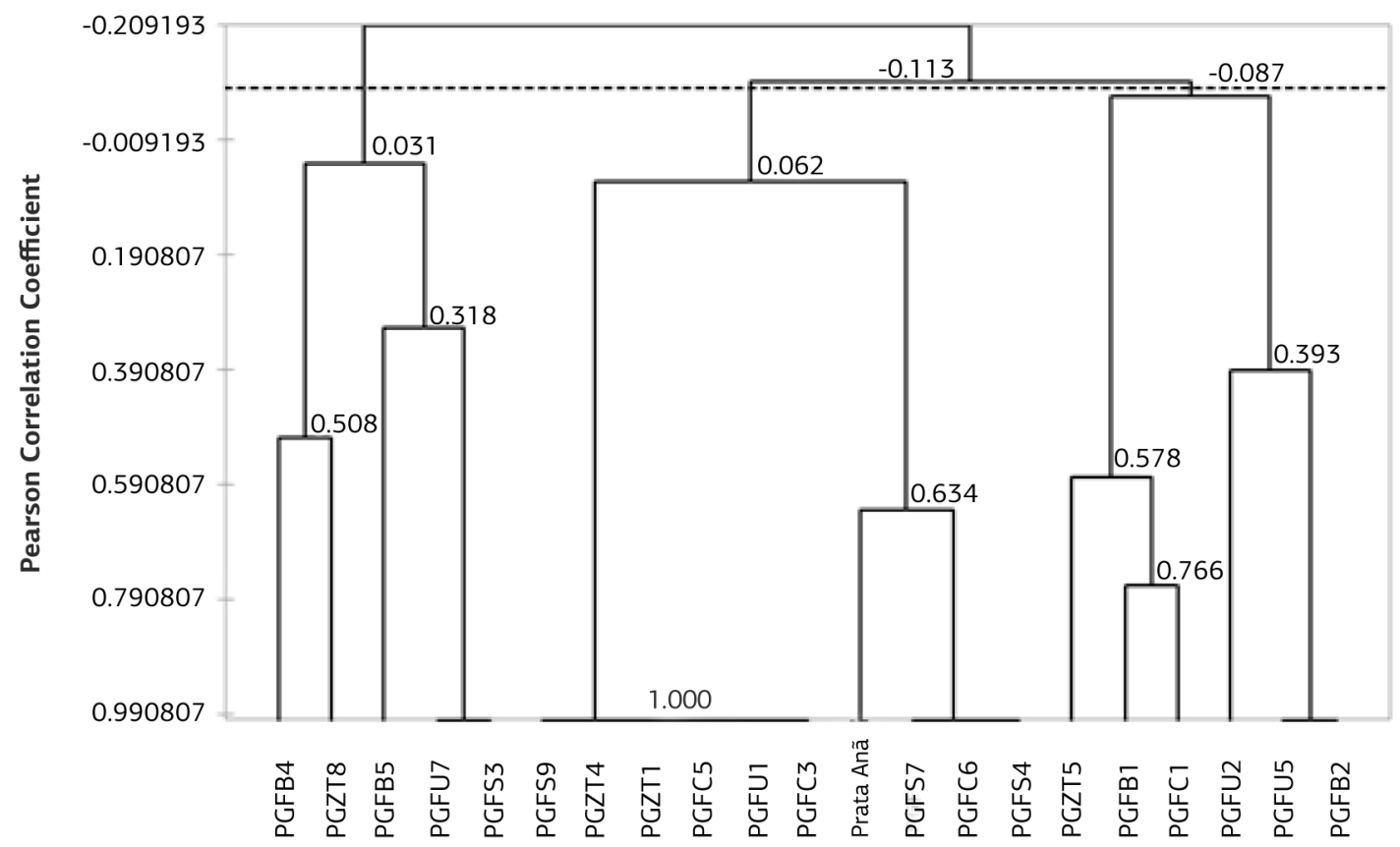

Figure 3. Distribution of the Pearson's correlation coefficients observed in the inflorescence characteristics (WAX, MAI, PAP, PLC, CAT, POL and ANE) of 21 'Prata Anä banana tree clones cultivated in northern Minas Gerais.

descriptor. Pillay and Tenkouano (2011) suggested that the variability within a clonal population is more phenotypic than genotypic and is often influenced by slight environmental differences within the habitat.

The amount of anthocyanin in the pseudostem (ANT) was another clearly differentiated descriptor among the evaluated clones. While the 'Prata Anä and 'Prata Anã Catarina' cultivars and clone PGFS 9 had pseudostems with a large distribution of anthocyanin, the other evaluated clones presented little anthocyanin in the external sheath. Genotypes with little pseudostem pigmentation tend to be more similar to the Musa balbisiana Colla species. Those with anthocyanin deposition and the presence of spots in the pseudostem tend to be similar to Musa acuminata Colla (STOver and Simmonds, 1987). The color of the pseudostem, petioles and midribs are considered minor changes and normally do not alter the nomenclature of the cultivar (PILlay and Tenkounano, 2011).

Clusters based on the BUS, FLX, PSF, MPR and BRP descriptors were classified into three distinct groups: group I was defined to include the 'Prata Anä' cultivar and clones PGFU 1, PGFS 4 and PGFS 9, showing a positive correlation of 0.297 with Group II and a negative correlation (-0.314) with Group III. Group III comprised 10 clones with $100 \%$ similarity (Figure 2 ).

The evaluated clones showed variability in the persistence of the remaining bract portions (BRP) in the rachis and the persistence of floral remains (MPR) on the male rachis. The MPR was only observed in the 'Prata Anä' banana cultivar, while in the other evaluated clones $62 \%$ of the plants presented floral remains along the entire rachis. The BRP in the 'Prata Aná Gorutuba' clones was 76\% differentiated from the 'Prata Anâ' cultivar, predominantly in plants that are commonly referred to as "dirty tail" plants, as described by (Moreira, 1999).

In all 20 'Prata Anã Gorutuba ' clones, it was observed that the older bunch on the inside of the stalk had crooked and curved fruit. The characteristics that differentiated the 'Prata Anã Gorutuba ' clones from the 'Prata Anä' cultivar included the shape (BUS) and flexion (FLX) of the bunch. In all evaluated clones, the clusters were compact, and the bunches were plain and slightly curved with extremely close insertions, clearly demonstrating cluster compaction, which was not observed in the 'Prata Anã. According to Nantale et al. (2008) a number of morphological characteristics are prone to mutations, including plant stature, bunch and fruit shapes and fruit pulp stringency. Despite the great importance of genetic variation, it is not known how these traits are selected and subsequently conserved within a given farming community.

A high level of homogeneity was observed among inflorescence characteristics (heart and male flowers), as only seven descriptors among the 25 evaluated presented more than one category class.

The 'Prata Anâ' was clustered in Group I and recorded a high correlation (1.000) with the PGFS7, PGFC6 and PGFS 4 clones. The other two groups (II and III) were clustered with $23.8 \%$ and $28.6 \%$ of the evaluated clones, respectively (Figure 3 ).

Although the presence of anthocyanin occurred in the 'Prata Anã' banana tree cultivar, 57\% of the 'Prata Anã 
Gorutuba' clones presented anthocyanin throughout the perianth, with the same characteristic detected in 'Prata Anã Catarina' (PGFS 9).

This characteristic presents great variation among the evaluated clones and requires careful observation because the flowers must be evaluated in the first week after the bract opens; after the first week, it is common for flowers to acquire a rosy hue, even those from clones with white or cream colored bases and perianths. Floral structure senescence also causes the darkening of some tissues and can lead to incorrect evaluations of these descriptors.

Jesus et al. (2009) reported similar observations of the varying states of some descriptors and the subjectivity of evaluation. According to the author, the pseudostem spot color descriptor, for example, could be considered a single color due to the difficulty in differentiating shades of brown. Similar suggestions have been made for mature fruit pulp color (white and white matte) and anther color (pale brown and cream).

Despite the difficulty of differentiating some qualitative characteristics, anthocyanin pigments are called melanins and are present in various parts of the plant. Various shades of red, brown, bronze and black can be observed along the pseudostem, petioles, upper sheaths and midribs. These variations are considered mutations and are useful for identifying clones (SIMMONDS, 1966).

Among the 74 evaluated characteristics, $37.5 \%$ of the plant characteristics, $12 \%$ of the cluster characteristics and $28 \%$ of the inflorescence characteristics presented more than one categorical class, which is equivalent to $12 \%, 4 \%$ and $9 \%$ of the total number of evaluated characteristics, respectively.

In general, a high rate of similarity was observed among the evaluated clones. Therefore, a study conducted with 'Mysore' banana clones revealed that the pseudostem girth, fruit maturity period, bunch, total, and average fruit weight and fruit circumference in the second comb had high genotypic variation (SIRISENA and Senanayake, 2000). Tezenas du Montcel et al. (1983) observed marked variability among plantains from Cameroon, although the sub-group was homogeneous from a botanical point of view. This author suggested that the morphological variability was due to some parental influences during the natural hybridization process and to certain mutations. In addition, an additional source of morphological variation is associated with the process of selection. Bunch and fruit characters experience tremendous selection pressure, particularly the compactness and shape of the bunch and fingers (Pillay and Tenkouano, 2011).

Morphological descriptors for the characterization of germplasm are not biased by the environment, should be scored easily and must have constant phenotypic expression. Meanwhile, descriptors that are affected by the environment are more important for agronomic evaluation or selection and for classification (ORTIZ, 1997).

\section{Molecular Characterization}

The fourteen RAPD primers produced a total of 176 bands, 116 monomorphic and 60 polymorphic. The average percentage of polymorphism was $52.2 \%$, with a low of $20 \%$ and a high of $88 \%$. The average number of polymorphic bands per primer was 4.28 , and the OPP 14, OPB 10, OPG 17, OPE 12, and OPU 10 primers generated the greatest number of polymorphic bands: 7, 6, 6, 6 and 6, respectively (Table 3 ). UMA et al. (2006) conducted a study to estimate the diversity between and within the M. balbisiana species. The authors demonstrated that, of the 80 random primers used, 34 produced reproducible bands and only four primers produced more than five polymorphic bands. The average polymorphism obtained was $74.6 \%$, indicating a considerable variation at the DNA level within M. balbisiana accessions.

The results of this and other studies demonstrate that a percentage of polymorphisms above $50 \%$ were observed for the intra - and inter cultivar genetic variability in species of the genus Musa. Studies conducted in different regions of Turkey using RAPD markers indicated a $61.3 \%$ polymorphism within the somaclonal variants of the Dwarf Cavendish cultivar (Gubbuk et al., 2004). In southern India, researchers evaluated the genetic variability of $21 \mathrm{com}$ mercial cultivars of banana by amplification using 50 RAPD primers and observed a $60.2 \%$ polymorphism (Venkatachalan et al., 2008).

The 'Prata Anã Gorutuba' clone PGFS 7, collected at the Jaíba city, Santa Odília farm, had the highest percentage of polymorphic bands, with an average dissimilarity of $13.2 \%$ when compared with the 'Prata Anä' cultivar. However, clone PGZT 12, named 'Prata Anã Rio', showed a similarity of $98.7 \%$ with the 'Prata Anä banana cultivar. Morphologically, the PGZT 12 clone had phenotypic characteristics that were similar to those of the 'Prata Anâ' cultivar in the field.

It was not possible to group the clones according to collection location or clone origin. When comparing the dissimilarity of the clones using collection location, the data indicated that the clones cultivated in Nova Porteirinha and Janaúba cities had a lower average dissimilarity percentage of 3.56 , whereas the clones that were cultivated at Janaúba e Jaíba cities had a higher average dissimilarity percentage of 5.23 .

The clones in this study presented a low dissimilarity and clustered with the common 'Prata Anä' cultivar. Jesus et al. (2009) showed that the RAPD markers were able to clearly distinguish the varieties according to their 
genomic groups but presented the lowest dissimilarity with RAPD markers, with most classes showing a dissimilarity value below $30 \%$.

According to the dendrogram, the clone PGFS 7 had the greatest dissimilarity when compared with the 'Prata Anä cultivar (Figure 4).

Studies indicate that the use of RAPD markers is efficient in separating cultivars that are derived from different genomic groups, but not for the characterization among clones (BHAT et al., 1995; VISSER, 2000).According to GuimarÁEs et al. (2009), the 103 RAPD primers and 33 pairs of SSR primers used did not produce polymorphic bands and were not efficient in distinguishing 'Prata Anä' (normal plants) from somaclonal variants. Conversely, Jesus et al. (2009) and Uma et al. (2009) recommend the use of SSR and AFLP markers for more refined and specific results.

The use of two molecular techniques combines the information generated from the broad coverage of the genome generated through the use of RAPD and the high

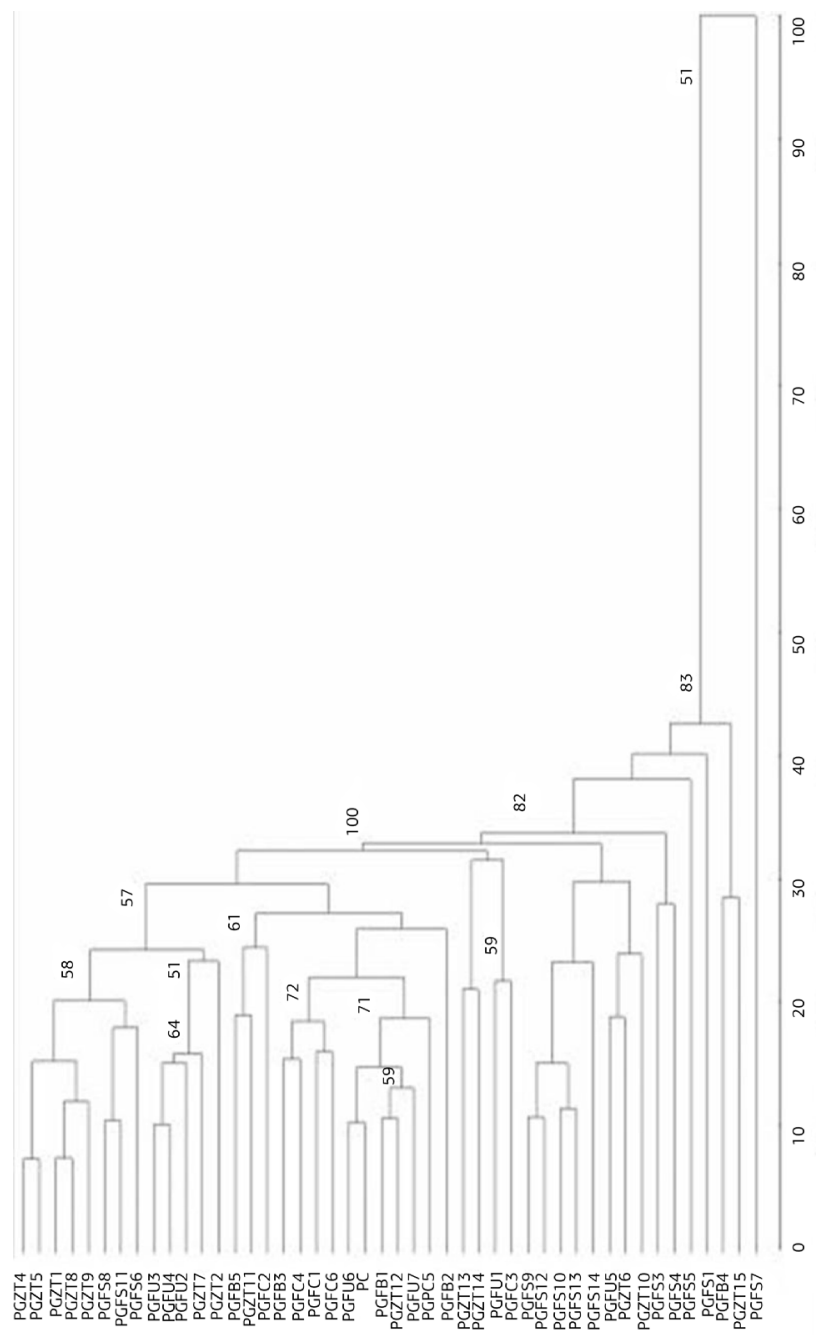

Figure 4. Dendrogram of similarity (\%) among 45 Prata Anã banana clones and the 'Prata Anä' cultivar derived from Jaccard's coefficient of similarity. Bootstrap values higher than $50 \%$. reproducibility of the SSR bands, which generate important, reliable and informative bands for the genotypes (Rocha et al., 2002).

Although all of the clones evaluated clustered with the 'Prata Anâ' cultivar, the identification and selection of superior clones is considered an important strategy in banana breeding programs.

\section{CONCLUSION}

Morphological descriptors, such as pseudostem color, presence of anthocyanin in the pseudostem, shape of the clusters and bunches, and the persistence of remaining flowers and bracts on the rachis were used to differentiate 'Prata Anẩ clones from the cultivar Prata Anã. All 45 'Prata' clones evaluated were grouped with the 'Prata Anä' cultivar using RAPD markers.

\section{ACKNOWLEDGMENTS}

The authors would like to thank FAPEMIG and CNPq for supporting this work.

\section{REFERENCES}

BHAT, K.V.; JARRET, R.L.; RANA, R.S. DNA profiling of banana and plantain cultivars using random amplified polymorphic DNA (RAPD) and restriction fragment length polymorphism (RFLP) markers. Electrophoresis, v.16, p.1736-1745, 1995.

BRAMMER, S.P. Marcadores moleculares: princípios básicos e uso em programas de melhoramento genético vegetal. Passo Fundo: Embrapa Trigo, 2000. 7p. (Embrapa Trigo. Documentos online, 3). Disponível em: <http://www.cnpt.embrapa.br/biblio/p_do03. htm>. Acesso em: 16/10/2010.

CRUZ, C.D. Programa Genes - Estatística Experimental e Matrizes. Viçosa: Editora UFV, 2006. 285p.

DAMASCO, O.P.; GRAHAM, G.C.; HENRY, R.J; ADKINS, S.W.; SMITH, M.K. Random amplified polymorphic DNA (RAPD) detection of dwarf off-types in micropropagated Cavendish (Musa spp. AAA) bananas. Plant Cell Reports, v.16, p.118-123, 1996.

DOYLE, J.J.; DOYLE, J.L. Isolation of plant DNA from fresh tissue. Focus, v.12, p.13-15, 1990.

GUBBUK, H.; PEKMEZCI, M.; NACI ONUS, A.; ERKAN, $M$. Identification and selection of superior banana phenotypes in the cultivar Dwarf Cavendish using agronomic characteristics and RAPD markers. Pakistan Journal of Botany, v.36, p.331-342, 2004.

GUIMARÁES, N.C.C.; TORGA, P.P.; RESENDE, E.C.; JÚNIOR, A.C.; PAIVA, E.; PAIVA, L.V. Identificação de variantes somaclonais em bananeiras 'Prata Anâ', utilizando 
técnicas moleculares e citogenéticas. Ciência e Agrotecnologia, v.33, p.448-454, 2009.

JESUS, O.N; FERREIRA, C.F; SILVA, S.O; CAMARA, T.R; SOARES, T.L; PESTANA, K.N. Characterization of recommended banana cultivars using morphological and molecular descriptors. Crop Breeding and Applied Biotechnology, v.9, p.164-173, 2009.

IPGRI - International Plant Genetic Resources Institute. Descriptors for banana (Musa spp.). Rome: FAOP-IPGRI-INIBAP, 1996. 55p.

LICHTEMBERG, L.A; LICHTEMBERG, P.S.F. Avanços na bananicultura brasileira. Revista Brasileira de Fruticultura, v.33, p.29-36, 2011.

MARQUES, P.R.R.; DONATO, S.L.R.; PEREIRA, M.C.T.; COELHO, E.F.; ARANTES, A.M. Características agronômicas de bananeiras tipo 'Prata' sob diferentes sistemas de irrigação. Pesquisa Agropecuária Brasileira, v.46, p.852-859, 2011.

MARTINS-LOPES, P.; GOMES, S.; LIMA-BRITO, J.; LOPES, J. Assessment of clonal genetic variability in Oleaeuropaea L. 'Cobrançosa' by molecular markers. Scientia Horticulturae, v.123, p.82-89, 2009.

MOREIRA, R.S. Banana: teoria e prática de cultivo. 2. ed. São Paulo: Fundação Cargill, 1999. CD-ROM.

NANTALE, G.; KAKUDIDI, E.K.; KARAMURA, D.A.; KARAMURA, E.; SOKA, G. Scientific basis for banana cultivar proportions on-farm in East Africa. African Crop Science Journal, v.16, p.41-49, 2008.

ORTIZ, R. Morphological variation in Musa germplasm. Genetic Resources and Crop Evolution, v.44, p.393-404, 1997.

PILLAY, M.; NWAKANMA, D.C.; TENKOUANO, A. Identification de RAPD markers linked to A and B genome sequences in Musa L. Genome, v.43, p.763-767, 2000.

PILLAY, M.; TENKOUANO, A. Banana Breeding: Progress and Challenges. Boca Raton, Florida: CRC Press, 2011.383p.

ROCHA, R.B.; MURO ABAD, J.I.; PIRES, I.E.; ARAÚJO, E.F. Fingerprinting and genetic diversity analysis of Eucalyptus spp. genotypes using RAPD and SSR makers. Scientia Forestalis, v.62, p.24-31, 2002.

RODRIGUES, F.E. Prata Gorutuba (Musa AAB Prata Ana Clone Gorutuba). Ficha Técnica. Disponível em: http://www.sbwbrasil.
com.br/Ficha\%20t\%C3\%A9cnica\%20Prata\%20Gorutba.pdf. Acesso em: 20/6/2009.

SILVA, S.O.; SHEPHERD, K.; ALVES, E.J. Cultivares de banana. In: ALVES, E.J. (Ed.). A Cultura da Banana: aspectos técnicos, socioeconômicos e agroindustriais. Brasília: Embrapa, 1997. p.85-105.

SIMMONDS, N.W. Bananas. 2. ed. London: Longmans, 1966. 512p.

SHINWARI, Z.K. Introduction of new techniques in biological sciences in Paquistan. I. Future Directions for Plant Systematics using RFLP. Science Technology Development, v.14, p.22-30, 1995.

SIRISENA, J.A.; SENANAYAKE, S.G.J.N. Estimation of variability parameters within 'Mysore' banana clones and their implication for crop improvement. Scientia Horticulturae, v.84, p.49-66, 2000.

SOLOUKI, M.; MEHDIKHANI, H.; ZEINALI,H.;EMAMJOMEH, A.A. Study of genetic diversity in chamomile (Matricaria chamomilla) based on morphological traits and molecular markers. Scientia Horticulture, v.117, p.281-287. 2008.

STOVER, R.H.; SIMONDS, N.W. Bananas. 3. ed. New York: Longmann, 1987. 468p.

TEZENAS DU MONTCEL, H.; DE LANGHE, E.; SWENNEN, R. Essai de classification des bananiers platain (AAB). Fruits, v.38, p.461-474, 1983.

UMA, S.; SIVA, S.A.; SARASWATHI, M.S.; MANICKAVASAGAM, M.; DURAI, P.; SELVARAJAN, R.; SATHIAMOORTHY, S.Variation and intraespecific relationships in India wild Musa balbisiana (BB) population as evidenced by random amplified polymorphic DNA. Genetic Resources and Crop Evolution, v.53, p.349-355, 2006.

VENKATACHALAM, L.; SREEDHAR, R.V.; BHAGYALAKSHMI, $\mathrm{N}$. The use of genetic markers for detecting DNA polymorphism, genotype identification and phylogenetic relationship among banana cultivars. Molecular Phylogenetics and Evolution, v.47, p.974-985, 2008.

VISSER, A.A. Characterization of banana and plantain using random amplified polymorphic DNA markers. Acta Horticulturae, n. 540, p.113-123, 2000.

WILLIAMS, J.G.K.; KUBELIK, A.R.; LIVAK, K.J. DNA polymorphisms amplified by arbitrary primers are useful as genetic markers. Nucleic Acids Research, v.18, p.6531-6535, 1990. 